In a helpful adjunct to Bicks's essay, Kent R. Lehnhof's 'Acting Virtuous: Chastity, Theatricality, and The Tragedie of Mariam' explores the definition and preservation of early modern chastity, which was always a female quality according to Lehnhof, and always to a certain extent a performance. For many early modern authors, "female virtue is not merely "imperfect" but utterly nonexistent' (220). Thus, the 'the all-too-familiar command that women be chaste, silent, and obedient does not insist upon real female virtue but only adumbrates a preferred performative role .... Women act chastely, in other words, to the extent they play a part not properly or naturally their own' $(221,222)$. Elizabeth Cary's play is radical in its depiction of the extent to which Mariam herself refuses to conform to masculine expectations for female chastity, which require her at the risk of her life to dissemble, to play at virtue. Lehnhof concludes that Mariam, 'unyielding in her antitheatrical sense of honesty, is the perfect hero for a closet drama intent on opposing itself to the popular state, where actors accommodate themselves to whatever is popular or profitable' (225).

On the whole, this collection is enjoyable and informative without being consistently provocative or groundbreaking. Several standout essays bring intellectual excitement or a fresh perspective to their subject matter, but some flattening repetition and thematic overlap is to be expected in a collection of this kind. Another perhaps minor problem that develops into a major annoyance is the number of typographical errors, especially in the book's first half: comma errors, missing or transposed words, faulty quotations. These mar the book's professionalism and otherwise consistently high level of scholarship.

\title{
Helen Smith. Grossly Material Things: Women and Book Production in Early Modern England. Oxford: Oxford University Press, 2012. Pp 254.
}

Christina Luckyj

Early Theatre 16.1 (2013), 201-5

Dalhousie University

doi: http://dx.doi.org/10.12745/et.16.1.17

As creator of Judith Shakespeare, the imaginary woman writer whose thwarted life becomes an object of mourning, Virginia Woolf has been much maligned by scholars for underestimating early modern women's literary production. In Helen Smith's book, Woolf makes something of a comeback: not 
only is the book's title drawn from her observation that writing is 'like a spider's web, ... attached to grossly material things', but her theories of androgyny are invoked to support Smith's central idea that 'the early modern book and its texts can be reconceptualized not as male or female-authored but as the interface at which numerous agents coincide, in complex and varied ways' (4). Woolf also makes a cameo appearance at the beginning of the book when, in a letter, she attributes her shaky handwriting to the physical toll of her compositorial work in setting the type of The Waste Land for Hogarth Press, evidence of her own participation in producing the male-authored text. Yet this book does more than simply scour the archives for similar traces of women's labour in an otherwise male-dominated book trade. Far from mere handmaids to their more accomplished male contemporaries, the early modern women who people this extraordinary book are revealed not only as patrons, printers, and translators of male-authored works, but also as stationers, chapwomen, and active readers who shape those works' very meanings. A welcome corrective to the familiar emphasis on prescriptive literature, Smith's work immerses us in the dirty, noisy world of early modern England where men and women jostled for position in the burgeoning economy of London and beyond. Building on existing scholarship on literary culture as highly collaborative, mobile, and open-ended, Smith adapts Robert Darnton's notion of a 'communications circuit' to propose Woolf's spider's web as an appropriate metaphor both for the complex interactions between human agents and material objects and for the highly tactile relation between bodies and the physical environment. This fascinating interdisciplinary study has much to offer historians and literary critics alike.

Chapter one, 'Women at the Scene of Writing', investigates women as scribes, translators, and editors working in collaboration with men. Beginning with the apparently menial business of women's labour as copyists, Smith draws attention not only to exceptional women like Esther Inglis whose extraordinary calligraphy framed her as an author in her own right but also to the many pious women who copied down the sermons they heard. Observing that both preacher and female copyist constructed themselves as instruments of divine will, Smith claims that 'the copyist is a co-labourer with the author or the divine word, reproducing, but also experiencing, the formative force of the text' (30). Similarly, she argues, women translators were engaged in a practice that was far from derivative or mechanical; rather, they were collaborators with their authors - and just as frequently deeply engaged in the same religio-political controversies. Even words such as 
'copy' and 'mirror', she reminds us, suggest both reflection and creation of a model for others to imitate. Women worked as editors, too, in the transmission of male-authored texts (the most famous example being the countess of Pembroke) as they memorialized their male relations. While Smith's argument is important in correcting the lingering (though fading) devaluation of women's textual work in these genres, one cannot help wondering if Anne Cooke, Anne Prowse, or Pembroke herself would have been rather astonished by the idea that her learned translations, certainly a mark of her aristocratic breeding, required defending in this way.

Chapter two, 'Women, Patronage, and Print', illuminates female patronage as a varied and capacious practice, ranging from phony celebrity endorsements to commissioned works emerging from intimate relationships and gift exchange. Thus women patrons might function as ideal readers informing the composition of a work, as commissioning agents in publication or manuscript circulation, or as unwitting advertising tools. In this chapter, Smith maps the presence of women in the emerging economy of patronage as commercial exchange, which co-existed with more traditional practices. Relations between patroness and author were complex, she argues: to reinforce their own cultural status female patrons might commission works from male authors, who in turn reaped social and political advantages at court and reached a wider audience through print. Women also patronized printers to promote the spread of vernacular literacy; here, another narrative might emerge, for many women patrons (including Mary Sidney and Katherine Brandon) were protestants or puritans actively committed to a public project of reform. As for Catholic women, their religious identity in this case was likely more important than gender. Indeed, much of what Smith writes about women's relation to the conditions of writing, patronage, and print could also be said about men. The book is especially interesting, then, when we learn something that is peculiar to women: that women translators tended to dedicate their labours to other women, for example (37).

In chapter three, 'Women and the Stationers', Smith mines the archives for any traces of women's activities, though, as she notes, much of the evidence is now either lost or obscured; we only know that girls were involved in menial work in the print shop, for example, because there is an edict ordering the master printer to do the work himself. It is well known that widows inherited their husbands' printing businesses, though many of them either remarried (another printer) or passed the business on to their sons. In this sense, Smith's argument for their genealogical 'labour' (105) looks a little like 
special pleading, as does her excavation of their role in providing linens for the Stationers' Hall. Far more compelling is the evidence she provides of the association of some women printers with radical causes: Elizabeth Purslowe, for example, was linked to 'seditious' pamphlets (91), several printers' wives were accused of printing radical material during the Civil War, and Anne Griffin faced down Archbishop Laud himself. (Griffin also probably printed Rachel Speght's 1621 Dreame of women's education, a fact Smith does not mention.)

Chapter four, "Certaine women brokers and peddlers": Beyond the London Book Trades', examines women who prosecuted their rights to patents and privileges as well as women who distributed printed books outside the capital. Sometimes at risk of becoming a laundry list of all women in any way connected with the book trade, the book is more satisfying when it pauses to consider a particular narrative: when, for example, in 1595, Jane Yetsweirt penned several letters to eminent men appealing her patented right (in her husband's name) to print books of English common law or when Margery Trundle became a household word as a printer and hawker of cheap print and ballads characterized by their 'cheerful misogyny' (151).

Chapter five, 'Imagining Early Modern Women Reading', returns us to the 'grossly material' with an absorbing discussion of reading as an intensely physiological activity. If we can speak of a book 'making an impression' on us, Smith reminds us, early moderns meant it literally - which is why women readers were urged to avoid arousing non-devotional material. Yet they were also far from passive, she argues; invoking Plato and Galen's notions of the eyes as active beams of light, men urged women readers to repair the deformities in their printed texts. Reading engaged not only the eyes, but the entire body - the ears, the digestion, and indeed the hands, as women incorporated creative pursuits such as needlework, writing, and talking into their reading 'recreation'. Susanna Howard, for example, loved reading Herbert's poems so much that she recited them from memory, sang them, and offered interpretations of them (207). Desdemona devouring Othello's stories takes on new meaning when read against the tale of one fond husband who instructed his wife to read a devotional book to the point of tearing it apart (188). With the advent of the e-book, we may have lost the early modern sense of the book not only as literal food for the soul but also as a sacred talisman whose curative properties resided in the 'girdle books' worn by so many women. In the end, Smith challenges the idea that books are 'grossly material things'. In her hands, they participate in 'networks of human actors, 
material goods, institutions and environments in ways which complicate the division between subjects and objects, those who act and that which is acted upon' (216). This complex and holistic approach to women's participation in the early modern book trade provides exhaustive evidence of women commissioning, producing, disseminating, consuming, and recreating the works of their male contemporaries, illuminating their essential role as full participants in humanist culture.

\section{Ayanna Thompson. Passing Strange: Shakespeare, Race and Contem- porary America. Oxford: Oxford University Press, 2011. Pp 224.}

Jami Rogers

University of Wolverhampton
Early Theatre 16.1 (2013), 205-7

doi: http://dx.doi.org/10.12745/et.16.1.18

With the election of Barack Obama as the forty-fourth President of the United States in 2008, much of the media chattered about the dawn of a post-racial America: a utopia where race was no longer an issue and equality had been achieved. The 'birther' movement seeking to discredit Obama as a US citizen and the spike in gun sales on his recent reelection may be seen as just two of the signs that race is still a dominant force in America. Ayanna Thompson's exceptional interrogation of race and cultural politics in contemporary uses of Shakespeare is a timely and important contribution to the national discourse on race.

What Thompson presents to her reader is not a narrative history of Shakespeare and race as they appear in America, but a series of interrelated case studies that cover multiple facets of the topic. Her examples appear on the surface to include a disparate collection of genres, considering the deconstruction of racial attitudes within non-Shakespearean films and novels as well as constructions of race in Othello. Thompson's investigation encompasses white, black, Hispanic, and Asian American attitudes to and experiences of race. She acknowledges that 'there are polemical moments in the book because this is a project that requires action and not just passive reflection' (14). For Thompson, the monograph sets out to 'reveal that it is not only our modern conceptions of race that need to be challenged, but also our modern conceptions of Shakespeare' (18). 